ordered ordinal regression with outcome treatment change and variables joints (66/68 count), skin (PASI), entheses (LEI and MASES), dactylitis (LDI) and axial disease (BASDAI)

Results: 323 patients had had baseline assessment in March 2016. Their average age was 50.0 years (SD 13.8) and $49 \%$ were male. $80 \%$ patients had arthritis (19\% monoarthritis, 39\% oligoarthritis and $23 \%$ polyarthritis), $9 \%$ had an enthesitis subtype, $2 \%$ axial disease and $9 \%$ dactylitis. Initial treatment consisted of methotrexate (MTX) $(52 \%)$, in $7 \%$ of other synthetic disease modifying antirheumatic drugs (sDMARDs) and due to treatment of psoriasis $3 \%$ biologicals. Within the different phenotypes MTX was most frequently started in polyarthritis $(84 \%)$ followed by oligoarthritis (63\%), monoarthritis $(33 \%)$ and other phenotypes $(5 \%)$. At 12 months $70 \%(n=148)$ stayed on the initial drug. Of those switched, 9 started MTX, within the initial MTX users $(n=74)$ almost equal percentages stopped, switched to metoject or biological (4\%). A smaller percentage $(2 \%)$ switch to leflunomide. Changes in medication were driven by swollen joint count and the presence of dactylitis (Table 1)

Conclusions: MTX was initiated in about half of the early PsA patients. The majority of patients were kept on the initial treatment strategy in first year. Failure on initial drug led to variation in subsequent drugs with additional start of other sdmards, switch subcutaneuous MTX, to other sdmards or to biological dmards. Treatment change was driven by Swollen Joint Count and presence of Dactylitis. Skin, Enthesis and Axial disease did not play a role in escalating treatment. Disclosure of Interest: None declared

DOI: 10.1136/annrheumdis-2017-eular.5922

\section{FRI0498 OUTCOMES ASSOCIATED WITH ACHIEVEMENT OF VARIOUS TREATMENT TARGETS IN PATIENTS WITH PSORIATIC ARTHRITIS RECEIVING ADALIMUMAB}

J. Smolen ${ }^{1}$, D. Aletaha ${ }^{1}$, D.D. Gladman ${ }^{2}$, Y. Zhang ${ }^{3}$, F. Ganz ${ }^{4} .{ }^{1}$ Medical University of Vienna, Vienna, Austria; ${ }^{2}$ University of Toronto, Toronto Western Hospital, Toronto, Canada; ${ }^{3}$ AbbVie, Inc., North Chicago, United States; ${ }^{4}$ AbbVie, Inc., Baar, Switzerland

Background: Various instruments are currently used for disease activity and outcome assessment in psoriatic arthritis (PsA). Some measures attempt to incorporate the total spectrum of psoriatic disease manifestations [eg, minimal disease activity (MDA)] while others focus on arthritis assessments [eg, disease activity index for PsA (DAPSA)]. Whether in patients (pts) with PsA it is sufficient to primarily consider joint disease aspects remains unclear.

Objectives: To compare DAPSA remission and low disease activity (LDA) with MDA and very low disease activity (VLDA) for the presence of residual abnormalities of the respective composing variables.

Methods: This post hoc analysis included pts with PsA receiving adalimumab (ADA) in one of two multicenter studies: ADEPT was a 24-week (wk), randomized, double-blind, placebo-controlled trial; ACCLAIM was a 12-wk, open-label study conducted in Canada in care settings that reflected usual practice. Frequencies of DAPSA remission/LDA and MDA/VLDA were summarized, and the individual PsA manifestations within these states were assessed. DAPSA was summed from the following continuous variables: swollen (66) and tender (68) joints, pt global assessment (PtGA, cm), pt pain (PP, $\mathrm{cm})$, and C-reactive protein (CRP, $\mathrm{mg} / \mathrm{dL}$ ). DAPSA remission was defined as $\leq 4$ and DAPSA LDA as $>4$ and $\leq 14$. MDA criteria were as follows: $\leq 1$ tender, $\leq 1$ swollen joint, $\leq 1$ entheseal point, $P P \leq 15 \mathrm{~mm}, \mathrm{PtGA} \leq 20 \mathrm{~mm}, \mathrm{HAQ} \leq 0.5$, and PASI $\leq 3$. MDA was calculated as fulfilling 5 of the 7 criteria, and VLDA calculated as fulfilling all 7 criteria. Data were as observed.

Results: Among 151 pts receiving ADA in ADEPT, 33 (22\%) each achieved DAPSA remission and LDA at wk 24, and $20(14 \%)$ and $11(7 \%)$ achieved MDA and VLDA, respectively. Pts achieving DAPSA LDA appeared to mirror those in MDA, with the exception of experiencing numerically higher PP, PtGA, and PASI scores at wk 24 (Table). Pts in DAPSA LDA did experience numerically lower SJC when compared with the MDA achievers, and, like MDA achievers, displayed little residual enthesitis. Only VLDA, but not MDA, could match the stringency of DAPSA remission, a finding that was confirmed through analysis of the ACCLAIM cohort.

\begin{tabular}{|c|c|c|c|c|c|c|c|c|}
\hline \multirow[b]{2}{*}{ Variable } & \multicolumn{2}{|c|}{$\begin{array}{l}\text { DAPSA LDA } \\
\text { (>4- } \leq 14)\end{array}$} & \multicolumn{2}{|c|}{$\begin{array}{c}\text { DAPSA Remission } \\
(\leq 4)\end{array}$} & \multicolumn{2}{|c|}{$\begin{array}{c}\text { MDA } \\
\text { (5 of } 7 \text { criteria) }\end{array}$} & \multicolumn{2}{|c|}{$\begin{array}{c}\text { V.DA } \\
\text { (all } 7 \text { criteria) }\end{array}$} \\
\hline & $\begin{array}{c}\text { ADEPT } \\
n=33\end{array}$ & $\begin{array}{c}\text { ACCLAIM } \\
n=37\end{array}$ & $\begin{array}{c}\text { ADEPT } \\
n=33\end{array}$ & $\begin{array}{c}\text { ACD.AIM } \\
n=7\end{array}$ & $\begin{array}{l}\text { ADEPT } \\
n=20\end{array}$ & $\begin{array}{c}\text { ACCLAIM } \\
n=32\end{array}$ & $\begin{array}{l}\text { ADEPT } \\
n=11\end{array}$ & $\begin{array}{c}\text { ACQ.AIM } \\
n=9\end{array}$ \\
\hline TIC, 0-78 & $3.1 \pm 2.96$ & $2.0 \pm 1.80$ & $0.3 \pm 0.73$ & $0.1 \pm 0.38$ & $3.4 \pm 5.85$ & $5.1 \pm 5.49$ & $0.1 \pm 0.30$ & $0.2 \pm 0.44$ \\
\hline $\operatorname{SIC}, 0-76$ & $1.7 \pm 2.00$ & $2.4 \pm 2.53$ & $0.7 \pm 1.36$ & $0.3 \pm 0.49$ & $4.0 \pm 7.97$ & $4.8 \pm 4.31$ & $0.1 \pm 0.30$ & $0.2 \pm 0.44$ \\
\hline $\begin{array}{l}\text { Pain, } 100 \\
\text { mm VAS }\end{array}$ & $\begin{array}{l}17.8 \pm \\
13.28\end{array}$ & $\begin{array}{l}18.9 \pm \\
16.66\end{array}$ & $1 \pm 4.38$ & $3.1 \pm 3.89$ & $8.9 \pm 7.03$ & $\begin{array}{l}14.3 \pm \\
14.55\end{array}$ & $4.8 \pm 3.92$ & $4.9 \pm 4.59$ \\
\hline $\begin{array}{l}\text { PtGA, } 100 \\
\text { mm VAS }\end{array}$ & $\begin{array}{l}17.2 \pm \\
11.92\end{array}$ & $\begin{array}{l}18.9 \pm \\
18.02\end{array}$ & $3.7 \pm 4.09$ & $1.9 \pm 2.67$ & $8.9 \pm 7.07$ & $\begin{array}{l}15.6 \pm \\
20.35\end{array}$ & $4.3 \pm 3.64$ & $4.4 \pm 4.88$ \\
\hline $\mathrm{CRP}, \mathrm{mg} / \mathrm{dL}$ & $0.4 \pm 0.77$ & $1.0 \pm 0.99$ & $0.2 \pm 0.18$ & $1.1 \pm 0.79$ & $0.3 \pm 0.30$ & $1.0 \pm 1.27$ & $0.2 \pm 0.16$ & $1.6 \pm 0.97$ \\
\hline PASI & $2.5 \pm 5.24$ & $1.7 \pm 1.47$ & $0.6 \pm 1.40$ & $1.3 \pm 0.58$ & $0.7 \pm 0.59$ & $2.0 \pm 3.02$ & $0.3 \pm 0.34$ & $1.2 \pm 0.55$ \\
\hline HAQ-DI & $0.4 \pm 0.46$ & $0.3 \pm 0.47$ & $0.1 \pm 0.39$ & $0.2 \pm 0.34$ & $0.2 \pm 0.40$ & $0.2 \pm 0.35$ & $0.0 \pm 0.12$ & $0.0 \pm 0.09$ \\
\hline Enthesitis & $0.1 \pm 0.40$ & $0.1 \pm 0.28$ & $0.1 \pm 0.24$ & $0.1 \pm 0.38$ & $0.2 \pm 0.37$ & $0.2 \pm 0.37$ & $0.0 \pm 0.00$ & $0.1 \pm 0.33$ \\
\hline $\begin{array}{l}\Delta m T S S, 0- \\
570\end{array}$ & $\begin{array}{l}-0.1 \pm \\
1.30\end{array}$ & N/A & $\begin{array}{c}-0.2 \pm \\
0.70\end{array}$ & $\mathrm{~N} / \mathrm{A}$ & $\begin{array}{c}-0.5 \pm \\
2.20\end{array}$ & $\mathrm{~N} / \mathrm{A}$ & $\begin{array}{c}-0.1 \pm \\
0.51\end{array}$ & N/A \\
\hline
\end{tabular}

DAPSA, disease activity index of psoriatic arthritis, MDA, minimal dise ase activity, VLDA, very low disease activity, TIC, tender joint count based on 78 joints; SJC, swollen joint count based on 76 joints, mm, millimeter; VAS, visual analos scale; PtGA, patient global asse ssment of dise ase activity; CRP, C-reactive protein; mg, milligram; dL, deciliter; PASI, psoriasis activity score index; HAQ-DI, health assessment questionnaire disability index; $m$ TSS, modified total Sharp score
However, VLDA allowed for numerically higher residual PP and PtGA levels when compared with DAPSA remission. Importantly, residual enthesitis did not differ among pts achieving DAPSA remission or VLDA. Irrespective of disease activity assessment, pts receiving ADA displayed little to no radiographic progression. Conclusions: In the ADEPT and ACCLAIM cohorts, pts who achieved DAPSA remission or VLDA demonstrated similar outcomes with respect to the individual components of both scores, despite the omission of several of these within the DAPSA. Given the DAPSA's continuous nature, its use may offer a good alternative to fulfillment of the VLDA criteria, but these results require confirmation in different pt populations.

Acknowledgements: AbbVie: study sponsor, contributed to design, data collection, analysis, interpretation, and abstract writing, review, and approval. Medical writing: Ben Wolfe of AbbVie.

Disclosure of Interest: J. Smolen Grant/research support from: AbbVie, Inc., Consultant for: AbbVie, Inc., D. Aletaha Grant/research support from: AbbVie, Inc., Pfizer, Grünenthal, Merck, Medac, UCB, Mitsubishi/Tanabe, Janssen, and Roche, Consultant for: AbbVie, Inc., Pfizer, Grünenthal, Merck, Medac, UCB, Mitsubishi/Tanabe, Janssen, and Roche, D. Gladman Grant/research support from: AbbVie, Inc., Amgen, Bristol-Myers Squibb, Celgene, Eli Lilly, Janssen, Pfizer, Novartis, and UCB, Y. Zhang Shareholder of: AbbVie, Inc., Employee of: AbbVie, Inc., F. Ganz Shareholder of: AbbVie, Inc., Employee of: AbbVie, Inc. DOI: 10.1136/annrheumdis-2017-eular.3762

\section{FRI0499 REAL-WORLD STUDY ON THE PATTERNS AND COST OF TREATMENT FAILURE IN PATIENTS WITH PSORIATIC ARTHRITIS USING US CLAIMS DATA}

K. Price ${ }^{1}$, E. Alemao ${ }^{1}$, L. Burns ${ }^{1}$, Z. Guo ${ }^{1}$, V. Anupindi ${ }^{2}$, S. Goday ${ }^{3}$. ${ }^{1}$ Bristol-Myers Squibb; ${ }^{2} \mathrm{Mu}$ Sigma, Princeton, United States; ${ }^{3} \mathrm{Mu}$ Sigma, Bangalore, India

Background: Current treatments for psoriatic arthritis (PsA) are associated with a range of limitations, e.g. side effects, safety concerns and inadequate efficacy. The economic burden of biologic (b)DMARD failure among patients (pts) with PsA is thought to be substantial, ${ }^{1}$ but there is a need to quantify this formally.

Objectives: To evaluate PsA treatment failure (i.e. discontinuation and switching rates) in a US managed care setting and its economic consequences.

Methods: Pts aged $\geq 18$ years with 2 diagnosis codes for PsA and 1 claim for a bDMARD from 1 Jan 2007 to 31 Mar 2015 in the Truven Health MarketScan ${ }^{\circledR}$ Database (Commercial and Supplemental Medicare) were eligible for the study. Pts were considered incident if they did not have a PsA diagnosis or a bDMARD prescription during 1 year prior to first PsA diagnosis in the study period, and as prevalent otherwise. Pts had a 1-year follow-up from first PsA diagnosis in the study period. The percentages of pts discontinuing a drug, switching to another drug or continuing on the same drug for 1 year from first date of treatment were reported. Healthcare costs for 1 year from initiation of the first bDMARD, (medical and drug costs associated with treatment failures) were reported as cost per-pt-per-month (PPPM), and a generalized linear model was used to analyse the cost after controlling for various demographic variables.

Results: Of the 18,632 pts treated with a bDMARD, $1298(6.97 \%)$ were incident and $17,334(93.03 \%)$ prevalent. Almost half $(n=8994 ; 48.27 \%)$ of the pts continued on the index bDMARD for 1 year. Treatment failed for the remaining pts, with 7852 (42.14\%) discontinuing, and 1630 (8.75\%; overlap $\leq 30$ days between drugs) and 156 (0.84\%; overlap > 30 days) switching. In the prevalent group, $8754(50.50 \%)$ pts continued on the index drug, 7043 (40.63\%) discontinued, and 1399 (8.07\%; overlap $\leq 30$ days) and 138 (0.79\%; overlap > 30 days) switched to another drug Among incident pts, only 240 (18.49\%) continued, 809 (62.33\%) discontinued and 231 (17.80\%; overlap $\leq 30$ days) and 18 (1.38\%; overlap $>30$ days) switched to another drug. Pts with an overlap $>30$ days were excluded from the analysis. Overall, pts who switched had a higher PPPM total cost $(\$ 3317)$ than those who discontinued $(\$ 2650 ; p<0.0001)$ or continued $(\$ 2708 ; p<0.0001)$. Similar results were observed in the prevalent and incident groups, respectively, with pts who switched incurring a higher PPPM total cost (\$3241 and \$3779) compared with those who discontinued $(\$ 2583$ and $\$ 3237$; both $\mathrm{p}<0.0001)$ or continued $(\$ 2700$ and $\$ 3080$; both $p<0.0001)$. Increasing age (per year) was associated with a $0.57 \%$ higher total cost in the incident group $(p=0.002)$ and with a $0.49 \%$ higher cost in the prevalent group $(\mathrm{p}<0.0001)$. Among prevalent pts, females had a $3.08 \%$ higher cost than males $(p=0.0069)$. The Charlson Co-morbidity Index score predicted a higher cost $(p<0.0001)$ among prevalent but not incident pts.

Conclusions: In a US claims study population of pts with PsA, rates of treatment failure as defined by switching or discontinuation were high. Follow-up costs for pts who switched were higher than for pts who continued or discontinued their medication. Baseline age, female sex and co-morbidities were associated with higher treatment costs.

References:

[1] Taylor PC, et al. Rheumatol Int 2016;36:685-95.

Disclosure of Interest: K. Price Employee of: Bristol-Myers Squibb, E. Alemao Shareholder of: Bristol-Myers Squibb, Employee of: Bristol-Myers Squibb, L. Burns Shareholder of: Bristol-Myers Squibb, Employee of: Bristol-Myers Squibb, Z. Guo Shareholder of: Bristol-Myers Squibb, Employee of: Bristol-Myers Squibb, V. Anupindi: None declared, S. Goday: None declared

DOI: 10.1136/annrheumdis-2017-eular.1476 